\title{
IDENTIFIKASI PEMAHAMAN KONSEP SISTEM REPRODUKSI DENGAN MENGGUNAKAN INSTRUMEN THREE TIER TEST DI LOMBOK BARAT
}

\section{IDENTIFICATION OF UNDERSTANDING THE CONCEPT OF THE REPRODUCTION SYSTEM USING THREE TIER TEST INSTRUMENTS IN WEST LOMBOK}

\author{
Surya Pratama*, Agil Al Idrus, Kusmiyati, dan Dadi Setiadi \\ Program Studi Pendidikan Biologi FKIP, Universitas Mataram, Mataram, Indonesia \\ *Email: $\underline{\text { Suryaprata46@gmail.com }}$
}

Diterima: 20 Oktober 2020. Disetujui: 9 November 2020. Dipublikasikan: 9 Januari 2021

\begin{abstract}
Abstrak: Penelitian ini bertujuan untuk mengidentifikasi pemahaman konsep sistem reproduksi siswa di Kelas XI MAN 1 Lombok Barat melalui penggunaan instrumen three tier test. Jenis penelitian ini adalah penelitian deskriptif. Populasi dalam penelitian ini adalah seluruh siswa kelas XI MAN 1 Lombok Barat (MIA, IPS dan Bahasa). Sampel penelitian ini sebanyak 60 siswa yang terdiri dari 30 siswa kelas XI MIA 1 dan 30 siswa kelas XI MIA 2. Pengambilan sampel penelitian dilakukan dengan teknik cluster sampling, yaitu teknik penentuan sampel berdasarkan perbedaan karakteristik kelas. Analisis dilakukan dengan pendekatan kuantitatif dan kualitatif menggunakan rumus persentase berdasarkan kriteria pemahaman konsep yang dicari. Hasil analisis pemahaman konsep sistem reproduksi dengan menggunakan instrumen three tier test didapatkan siswa yang paham konsep sebanyak $17.54 \%$ (klasifikasi rendah), siswa kurang paham konsep $0.93 \%$ (klasifikasi rendah), siswa mengalami miskonsepsi 76.20\% (klasifikasi sangat tinggi), siswa tidak paham konsep 3.53\% (klasifikasi rendah), dan siswa menebak $1.80 \%$ (klasifikasi rendah). Kesimpulan dari hasil penelitian menunjukkan bahwa siswa teridentifikasi mengalami miskonsepsi sangat tinggi pada konsep-konsep pemahaman yang rendah maupun yang membutuhkan pemahaman tinggi.
\end{abstract}

Kata kunci: three tier test, pemahaman konsep, sistem reproduksi.

\begin{abstract}
The purpose of this research is to identify the percentages of students concept capability of reproduction system materials in grade XI Islamic Senior High School 1 West Lombok by using the three tier test instrument. The type of this research is descriptive research. The population in this research were all students of grade XI Islamic Senior High School 1 West Lombok (Sains, Social and Language). The sample of this research was 60 students consisting of 30 students in grade XI MIA 1 and 30 students in grade XI MIA 2. Sampling was done by cluster sampling technique, which was sampling technique base on differences in class characteristics. The analysis was carried out with quantitative and qualitative approaches by using a percentage formula based on the criteria for understanding the concept being sought. The results of the students concept capability of reproduction system identified using the three tier test instrument shown that students who understood the concept about $17.54 \%$ (low classification), students not really understand the concept about $0.93 \%$ (low classification), students who experience misconception about $76.20 \%$ (very high classification), students do not understand the concept about 3.53\% (low classification), and students error/guess about $1.80 \%$ (low classification). The conclusion from the results of the study showed that students were identified as having very high misconceptions on concepts of low understanding and those requiring high understanding.
\end{abstract}

Keywords: three tier test, concept understanding, reproduction system.

\section{PENDAHULUAN}

Ilmu Pengetahuan Alam (IPA) berkaitan dengan cara mencari tahu tentang fenomena alam secara sistematis, sehingga IPA bukan hanya penguasaan kumpulan pengetahuan dan hasil (produk) saja akan tetapi juga merupakan suatu proses penemuan. Pendidikan IPA diarahkan untuk mencari tahu dan berbuat sehingga dapat membantu siswa untuk memperoleh pemahaman yang lebih mendalam tentang alam sekitar [1]. Untuk dapat memahami biologi secara luas, maka harus dimulai dengan kemampuan penguasaan konsep dasar pada pelajaran biologi. Berhasil atau tidaknya seorang siswa dalam memahami tentang pelajaran biologi sangat ditentukan oleh penguasaan konsep.
Menurut Nardi [2], pemahaman (comprehension) adalah kemampuan seseorang untuk mengerti sesuatu setelah sesuatu itu diketahui dan diingat. Pemahaman adalah proses dari pembelajaran bermakna, pembelajaran bermakna adalah dasar untuk memahami proses terjadinya pengetahuan. Menurut teori Ausubel, pembelajaran bermakna berbeda dengan pembelajaran di luar kepala (hafalan), untuk belajar secara bermakna siswa harus memilih pengetahuan baru untuk konsep yang benar dengan pengetahuan yang mereka miliki sebelumnya. Sedangkan pembelajaran di luar kepala (hafalan) pengetahuan baru diperoleh secara sederhana dengan ingatan secara verbal dan acak, dalam penggabungannya pada struktur pengetahuan yang 
dimiliki tidak memperhatikan pengetahuan yang dimilikinya.

Konsep merupakan ide abstrak yang dengannya kita dapat mengelompokkan obyek-obyek kedalam contoh atau bukan contoh. keterkaitan antara konsep materi satu dan yang lainnya merupakan bukti akan pentingnya pemahaman konsep. Karenanya, siswa belum bisa memahami suatu materi jika belum memahami materi sebelumnya atau materi prasyarat dari materi yang akan pelajari [3].

Pemahaman konsep merupakan kemampuan seseorang dalam mengetahui atau memahami, menganalisis, membedakan, memberikan contoh, menerapkan, menuliskan kembali, dan menyimpulkan suatu konsep yang telah dipelajari sebelumnya. Menurut Sudijono [4] pemahaman adalah kemampuan seseorang untuk mengerti atau memahami sesuatu setelah sesuatu itu diketahui dan diingat. Pemahaman konsep bagi siswa sangatlah penting karena konsep merupakan abstraksi dari ciriciri sesuatu yang mempermudah komunikasi antara manusia dan memungkinkan manusia untuk berpikir. Pemahaman terhadap konsep dan struktur suatu materi menjadikan materi itu dipahami secara lebih komprehensif.

Pengaruh Pemahaman konsep yang dimiliki siswa sangat dipengaruhi oleh kemampuan konsepsi setiap siswa atau tafsiran setiap siswa terhadap suatu konsep. Siswa datang ke kelas dengan membawa konsepsi maupun pengetahuan awal mengenai suatu konsep atau penjelasan suatu fenomena sebagaimana yang mereka lihat dengan mata sendiri. Penjelasan terhadap fenomena atau konsepsi tersebut terkadang tidak sesuai dengan penjelasan secara ilmiah. Hal ini dapat mengakibatkan kesalahan dalam memahami konsep atau memunculkan konsep alternatif yang jika tidak diubah akan terus terintegrasi dalam struktur kognitif siswa [5]. Hal ini dapat mengakibatkan timbulnya miskonsepsi pada siswa.

Miskonsepsi merupakan pemahaman suatu konsep atau prinsip yang tidak konsisten dengan penafsiraan atau pandangan yang berlaku umum tentang konsep tersebut. Konsepsi pada umumnya dibangun berdasarkan akal sehat (common sense) atau dibangun secara intuitif dalam upaya memberi makna terhadap dunia pengalaman mereka sehari-hari dan hanya merupakan eksplanasi pragmatis terhadap dunia realitas [6]. Miskonsepsi sangat sulit diubah, karena setiap orang membangun pengetahuan persis dengan pengalamannya. Sekali seseorang telah membangun pengetahuan, maka tidak mudah untuk memberi tahu bahwa hal tersebut salah dengan jalan hanya memberi tahu untuk mengubah miskonsepsi itu. Jadi cara untuk mengubah miskonsepsi adalah dengan jalan mengkonstruksi konsep baru yang lebih cocok untuk menjelaskan pengalaman [7].

Instrumen dari berbagai jenis telah digunakan untuk mengidentifikasi pemahaman konsep siswa seperti kuesioner, pertanyaan berupa uraian, dan pertanyaan berupa pilihan ganda.
Berdasarkan hasil wawancara yang dilakukan peneliti dengan siswa kelas XI MAN 1 Lombok Barat, umumnya instrumen soal yang biasa digunakan guru biologi di sekolah yaitu instrumen soal dalam bentuk pilihan ganda dan essay. Bentuk soal essay lebih sering digunakan karena soal jenis ini lebih dapat mengungkap pengetahuan siswa lebih dalam dan soal jenis ini dianggap dapat mengurangi tindak kecurangan, namun unsur subyektifitas sering kali terlibat dalam penilaiannya, sedangkan soal pilihan ganda digunakan karena mempermudah proses penilaian dan mengurangi subyektifitas dalam penilaian, namun tindak kecurangan lebih dapat dilakukan oleh siswa pada soal jenis ini. Peneliti juga memperoleh keterangan bahwa guru biologi tidak pernah melakukan pengukuran pemahaman konsep siswa. Hal ini menunjukkan bahwa tidak adanya tes diagnostik yang tersedia untuk mengungkap pemahaman konsep yang dialami oleh siswa. Menurut Surapranata [8], tes diagnostik digunakan sebagai alat untuk memperbaiki kesulitan belajar yang dialami oleh peserta tes dalam hal ini adalah siswa. Tes diagnostik dirancang secara khusus untuk mengidentifikasi kesulitan belajar siswa. Manfaat yang diperoleh dari pelaksanaan tes diagnostik adalah untuk membantu guru dalam pelaksanaan progam remidial. Untuk mengetahui ada tidaknya kesalahan konsep yang dialami siswa, maka dibutuhkan instrumen yang dapat mengukur tingkat pemahaman siswa dalam pelajaran biologi materi sistem reproduksi.

Alat yang dapat digunakan untuk mengidentifikasi pemahaman konsep siswa, salah satunya adalah instrumen Three Tier Test yaitu soal pilihan ganda dengan tiga tingkat pertanyaan dimana tingkat pertama menanyakan materi, tingkat ke dua menanyakan alasan dari jawaban tingkat pertama, dan tingkat ke tiga berupa indeks keyakinan siswa dalam menjawab. Kelebihan dari instrument Three Tier Test adalah dapat mengidentifikasi pemahaman konsep peserta didik dengan mudah dan tidak membutuhkan banyak waktu, dapat mengetahui kemungkinan peserta didik yang menjawab salah karena mengalami miskonsepsi atau tidak memahami materi [9]. Penggunaan instrumen three tier test ini diharapkan mampu menjadi alternatif bagi guru untuk mengukur pemahaman konsep siswa. Sehingga hasil yang mungkin diperoleh dari penelitian ini yakni besar persentase paham konsep, kurang paham konsep, miskonsepsi, tidak paham konsep, dan menebak.

Sistem reproduksi manusia merupakan salah satu konsep dalam biologi yang memerlukan tingkat pemahaman konsep tinggi serta sangat erat kaitannya dengan kehidupan sehari-hari. Materi ini mempunyai sub konsep-sub konsep yang saling berkaitan yang memungkinkan siswa untuk memahaminya diperlukan pemahaman awal terhadap materi tersebut, jika pemahaman awal siswa tidak kuat, maka untuk memahami sub konsep berikutnya akan rentan mengalami miskonsepsi. 
Pemahaman konsep sistem reproduksi pada siswa cukup berpengaruh terhadap hasil belajar, hal ini dikarenakan kesalahan dalam memahami konsep dapat menghambat pemahaman konsep, sebab materi sistem reproduksi saling berkaitan erat dan merupakan kunci untuk memahami konsep lain. Sehingga berdasarkan latar belakang tersebut, peneliti tertarik untuk melakukan penelitian dengan mengangkat judul Identifikasi Pemahaman Konsep Sistem Reproduksi dengan Menggunakan Instrumen Three Tier Test di Kelas XI MAN 1 Lombok Barat Tahun Ajaran 2019/2020.

\section{METODE PENELITIAN}

Penelitian ini merupakan penelitian deskriptif. Populasi dalam penelitian ini adalah seluruh siswa kelas XI MIA MAN 1 Lombok Barat. Teknik pengambilan sampel dalam penelitian ini adalah cluster sampling, dimana teknik pengambilan sampel yang digunakan berdasarkan perbedaan karakterik sesuai dengan kriteria kelas yang mempelajari materi sistem reproduksi yaitu melibatkan 30 siswa kelas XI MIA 1 dan 30 siswa kelas XI MIA 2. Pengumpulan data dilakukan dengan pemberian tes dalam bentuk tes diagnostik Three Tier Test alasan terbuka. Analisis data dilakukan dengan pendekatan kuantitatif dan kualitatif menggunakan rumus persentase berdasarkan kriteria pemahaman konsep yang dicari.

\section{HASIL DAN PEMBAHASAN}

Pemahaman konsep siswa terhadap suatu materi terdiri dari lima kategori, yaitu: paham konsep, kurang paham konsep, miskonsepsi, tidak paham konsep, dan menebak. Siswa dikatakan paham konsep jika siswa tersebut bisa menjelaskan konsep atau dapat diartikan siswa mampu untuk mengungkapkan kembali apa yang telah dikomunikasikan kepadanya. Selain itu siswa yang paham konsep dapat menggunakan konsep pada berbagai situasi yang berbeda dan mengembangkan beberapa akibat dari adanya suatu konsep atau dapat diartikan bahwa siswa paham terhadap suatu konsep akibatnya siswa mempunyai kemampuan untuk menyelesaikan setiap masalah dengan benar [10].

Terdapat tiga indikator utama pemahaman konsep yang menjadi landasan dalam menyusun item soal three tier test pada materi sistem reproduksi. Indikator pertama adalah menjelaskan (Explaining), indikator kedua adalah menentukan (Determining) dan indikator ketiga adalah menganalisis (Analyzing). Instrumen soal three tier test yang terdiri dari 25 soal yang valid diberikan kepada 30 siswa kelas XI MIA 1 dan 30 siswa kelas XI MIA 2 MAN 1 Lombok Barat. Hasil tes instrumen tersebut dianalisis kategori pemahaman konsep siswa yang dicari. Persentase pemahaman konsep siswa per butir soal dapat dilihat pada Tabel 1.

Saat menjawab soal three tier test, siswa yang paham konsep menjawab tier pertama dan tier kedua dengan benar, serta siswa tersebut yakin terhadap jawabannya. Hasil yang diperoleh pada Gambar 1 menunjukkan bahwa siswa paling banyak memahami konsep pada indikator 1 sebesar $30 \%$ yang diklasifikasikan rendah sedangkan yang paling sedikit memahami konsep pada indikator 8 sebesar $11.67 \%$ yang diklasifikasikan rendah. Pada indikator 1 tersebut siswa paling banyak memahami konsep organ reproduksi pria pada soal nomor 2 . Hal ini dapat dipengaruhi oleh indikator 1 yang memiliki tingkat ranah kognitif C2 (menjelaskan) sehingga mudah bagi siswa dalam mengingat konsep yang diperolehnya walaupun diklasifikasikan rendah, dibandingkan dengan ranah kognitif C4 (menganalisis) yang membutuhkan kemampuan berpikir tingkat tinggi sehingga siswa tidak mudah menemukan cara dalam penyelesaian masalah. Dimana soal dengan tingkat ranah kognitif rendah maupun tinggi menunjukkan bahwa mayoritas siswa tidak memahami konsep sistem reproduksi, karena konsep yang dipelajarinya tidak sesuai dengan konsep yang dikemukakan oleh pakar atau ahli. Hal ini didukung oleh Suparno [11] memaparkan bahwa siswa yang menjawab sesuai dengan konsep yang benar dapat terhindar dari adanya miskonsepsi, sebaliknya siswa yang menjawab tidak sesuai dengan konsep yang benar dapat menimbulkan terjadinya miskonsepsi.

Siswa yang kurang paham konsep dapat diidentifikasi dengan melihat pola jawaban three tier test. Siswa tersebut menjawab dengan benar pada tier pertama dan tier kedua, tetapi tidak yakin terhadap jawabannya. Hal tersebut menjelaskan bahwa sebenarnya siswa cukup paham terhadap konsep tersebut tetapi mereka ragu apakah konsep yang mereka pahami itu benar atau tidak. Ketidakyakinan tersebut disebabkan oleh siswa yang hanya paham sebagian konsep, karena jika siswa paham seluruh konsep maka siswa tidak akan ragu terhadap jawabannya.

Hasil yang diperoleh pada Gambar 2 menunjukkan bahwa siswa yang kurang paham konsep paling banyak teridentifikasi pada indikator 7 sebesar $2.50 \%$ yang diklasifikasikan rendah dan siswa yang kurang paham konsep paling sedikit pada indikator 1 sebesar $0.00 \%$ yang diklasifikasikan rendah. Pada indikator 7 tersebut siswa paling banyak kurang memahami konsep siklus menstruasi pada soal nomor 18. Siswa yang kurang paham konsep ini muncul karena pemahaman siswa terhadap suatu materi yang tidak utuh. Hal ini bisa terjadi karena kurangnya penekanan guru dalam penyampaian materi sebab pembelajaran yang dilakukan melalui daring/online. Hal ini didukung oleh Hairy [12] yang menyatakan bahwa guru seharusnya lebih menekankan dalam hal pemahaman konsep, karena dengan pemahaman inilah materi bisa terkuasai untuk jangka waktu yang lama dan miskonsepsi pun dapat diminimalisir. 
Tabel 1. Persentase Pemahaman Konsep Siswa Berdasarkan Jawaban Three Tier Test

\begin{tabular}{|c|c|c|c|c|c|c|c|c|}
\hline \multicolumn{3}{|c|}{ Indikator Pemahaman Konsep } & Nomor & PK & KPK & $\mathrm{M}$ & TPK & ER \\
\hline \multirow{5}{*}{$\begin{array}{l}\text { Menjelaskan } \\
\text { (Explaining) }\end{array}$} & \multirow{3}{*}{\multicolumn{2}{|c|}{$\begin{array}{l}\text { Siswa dapat menjelaskan } \\
\text { struktur dan fungsi organ } \\
\text { atau alat reproduksi pada } \\
\text { pria dan wanita. }\end{array}$}} & 1 & $25 \%$ & $0.00 \%$ & $75 \%$ & $0.00 \%$ & $0.00 \%$ \\
\hline & & & 2 & $33.33 \%$ & $0.00 \%$ & $65 \%$ & $0.00 \%$ & $1.67 \%$ \\
\hline & & & 3 & $31.67 \%$ & $0.00 \%$ & $65 \%$ & $0.00 \%$ & $3.33 \%$ \\
\hline & \multirow{2}{*}{\multicolumn{2}{|c|}{$\begin{array}{l}\text { Siswa dapat menjelaskan } \\
\text { gangguan atau kelainan } \\
\text { pada struktur dan fungsi } \\
\text { organ reproduksi }\end{array}$}} & 27 & $15 \%$ & $1.67 \%$ & $76.66 \%$ & $5 \%$ & $1.67 \%$ \\
\hline & & & 29 & $21.67 \%$ & $1.67 \%$ & $73.33 \%$ & $3.33 \%$ & $0.00 \%$ \\
\hline \multirow{12}{*}{$\begin{array}{l}\text { Menentukan } \\
\text { (Determining) }\end{array}$} & \multirow{4}{*}{\multicolumn{2}{|c|}{$\begin{array}{l}\text { Siswa dapat menentukan } \\
\text { proses pembentukan } \\
\text { spermatosit dan oosit pada } \\
\text { manusia. }\end{array}$}} & 5 & $26.67 \%$ & $0.00 \%$ & $73.33 \%$ & $0.00 \%$ & $0.00 \%$ \\
\hline & & & 6 & $20 \%$ & $0.00 \%$ & $68.34 \%$ & $3.33 \%$ & $8.33 \%$ \\
\hline & & & 7 & $21.67 \%$ & $1.67 \%$ & $70 \%$ & $3.33 \%$ & $3.33 \%$ \\
\hline & & & 8 & $18.33 \%$ & $0.00 \%$ & $70 \%$ & $6.67 \%$ & $5 \%$ \\
\hline & \multirow{4}{*}{\multicolumn{2}{|c|}{$\begin{array}{l}\text { Siswa dapat menentukan } \\
\text { peristiwa yang terjadi pada } \\
\text { siklus menstruasi. }\end{array}$}} & 13 & $13.33 \%$ & $0.00 \%$ & $83.33 \%$ & $1.67 \%$ & $1.67 \%$ \\
\hline & & & 14 & $6.67 \%$ & $0.0 \%$ & $91.67 \%$ & $1.67 \%$ & $0.00 \%$ \\
\hline & & & 15 & $21.67 \%$ & $0.00 \%$ & $78.33 \%$ & $0.00 \%$ & $0.00 \%$ \\
\hline & & & 16 & $16.67 \%$ & $1.67 \%$ & $80 \%$ & $0.00 \%$ & $1.67 \%$ \\
\hline & \multirow{4}{*}{\multicolumn{2}{|c|}{$\begin{array}{l}\text { Siswa dapat menentukan } \\
\text { hormon yang berperan } \\
\text { dalam proses kehamilan } \\
\text { sampai kelahiran }\end{array}$}} & 20 & $8.33 \%$ & $3.33 \%$ & $81.67 \%$ & $5 \%$ & $1.67 \%$ \\
\hline & & & 21 & $10 \%$ & $3.33 \%$ & $76.66 \%$ & $8.33 \%$ & $1.67 \%$ \\
\hline & & & 22 & $21.67 \%$ & $0.00 \%$ & $76.66 \%$ & $1.67 \%$ & $0.00 \%$ \\
\hline & & & 23 & $20 \%$ & $0.00 \%$ & $78.33 \%$ & $1.67 \%$ & $0.00 \%$ \\
\hline \multirow{9}{*}{$\begin{array}{c}\text { Menganalisis } \\
\text { (Analyzing) }\end{array}$} & \multirow{3}{*}{\multicolumn{2}{|c|}{$\begin{array}{l}\text { Siswa dapat menyimpulkan } \\
\text { proses pembentukan sperma } \\
\text { dan ovum }\end{array}$}} & 9 & $10 \%$ & $0.00 \%$ & $78.33 \%$ & $10 \%$ & $1.67 \%$ \\
\hline & & & 10 & $16.67 \%$ & $0.00 \%$ & $75 \%$ & $3.33 \%$ & $5 \%$ \\
\hline & & & 11 & $11.67 \%$ & $1.67 \%$ & $80 \%$ & $5 \%$ & $1.67 \%$ \\
\hline & \multirow{2}{*}{\multicolumn{2}{|c|}{$\begin{array}{l}\text { Siswa dapat } \\
\text { mengidentifikasi siklus } \\
\text { menstruasi pada wanita }\end{array}$}} & 17 & $18.33 \%$ & $1.67 \%$ & $76.66 \%$ & $3.33 \%$ & $0.00 \%$ \\
\hline & & & 18 & $15 \%$ & $3.33 \%$ & $73.33 \%$ & $6.67 \%$ & $1.67 \%$ \\
\hline & \multirow{3}{*}{\multicolumn{2}{|c|}{$\begin{array}{l}\text { Siswa dapat menelaah } \\
\text { proses pembuahan dan } \\
\text { perkembangan embrio }\end{array}$}} & 24 & $11.67 \%$ & $1.67 \%$ & $81.67 \%$ & $5 \%$ & $0.00 \%$ \\
\hline & & & 25 & $13.33 \%$ & $1.67 \%$ & $71.67 \%$ & $8.33 \%$ & $5 \%$ \\
\hline & & & 26 & $10 \%$ & $0.00 \%$ & $85 \%$ & $5 \%$ & $0.00 \%$ \\
\hline & \multicolumn{3}{|c|}{ Total } & $17.54 \%$ & $0.93 \%$ & $76.20 \%$ & $3.53 \%$ & $1.80 \%$ \\
\hline Keterangan: & \multicolumn{3}{|c|}{$\begin{array}{ll}\text { PK } & =\text { Paham Konsep } \\
\text { KPK } & =\text { Kurang Paham Konsep } \\
\text { M } & =\text { Miskonsepsi } \\
\text { TPK } & =\text { Tidak Paham Konsep } \\
\text { ER } & =\text { Error / Menebak }\end{array}$} & & & & & \\
\hline
\end{tabular}

Kategori pemahaman konsep siswa selanjutnya adalah miskonsepsi. Miskonsepsi merupakan suatu konsepsi seseorang (siswa) yang tidak sesuai dengan konsepsi ilmiah yang diakui oleh para ahli. Terdapat tiga pola jawaban siswa yang mengalami miskonsepsi. Pertama, siswa menjawab tier pertama benar, tetapi tier kedua salah, dan siswa yakin terhadap jawabannya. Kedua, siswa menjawab salah pada tier pertama, tetapi tier kedua benar, dan siswa yakin terhadap jawabannya. Ketiga, siswa menjawab tier pertama dan tier kedua salah, tetapi yakin terhadap jawabannya.

Hasil yang diperoleh pada Gambar 3 menunjukkan bahwa siswa paling banyak mengalami miskonsepsi pada indikator 4 sebesar $83.33 \%$ yang diklasifikasikan sangat tinggi dan siswa yang mengalami miskonsepsi paling sedikit pada indikator
1 sebesar $68.33 \%$ yang diklasifikasikan tinggi. Pada indikator 4 tersebut siswa paling banyak mengalami miskonsepsi pada konsep siklus menstruasi yaitu soal nomor 14. Ada beberapa miskonsepsi yang terjadi pada siswa, salah satunya adalah siswa beranggapan bahwa ovulasi itu terjadinya pelepasan sel telur dari ovum. Sedangkan ovum adalah sel telur. Konsep yang benar ialah ovulasi adalah pelepasan sel telur dari ovarium. Hal ini didukung oleh pendapat Campbell [13] yang menyatakan bahwa ovulasi terjadi karena hormone FSH dikeluarkan oleh tubuh. Sebetulnya FSH (Folikel Stimulating Hormon) berfungsi merangsang perkembangan folikel telur dan selsel folikel yang sedang tumbuh tersebut akan menyekresi kan estrogen, sedangkan hormon yang merangsang terjadinya ovulasi adalah LH (Luteinizing Hormon). 

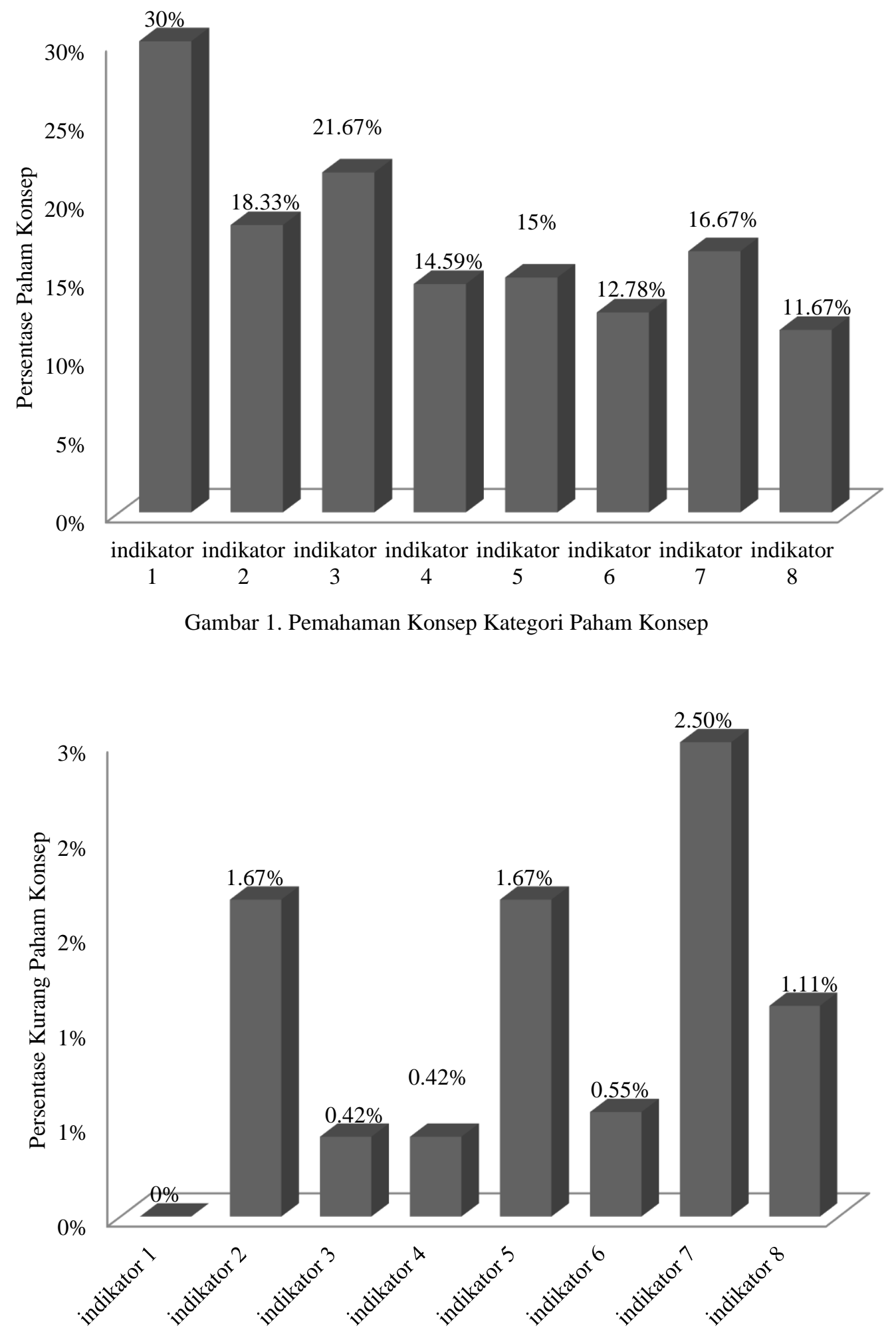

Gambar 2. Pemahaman Konsep Kategori Kurang Paham Konsep 


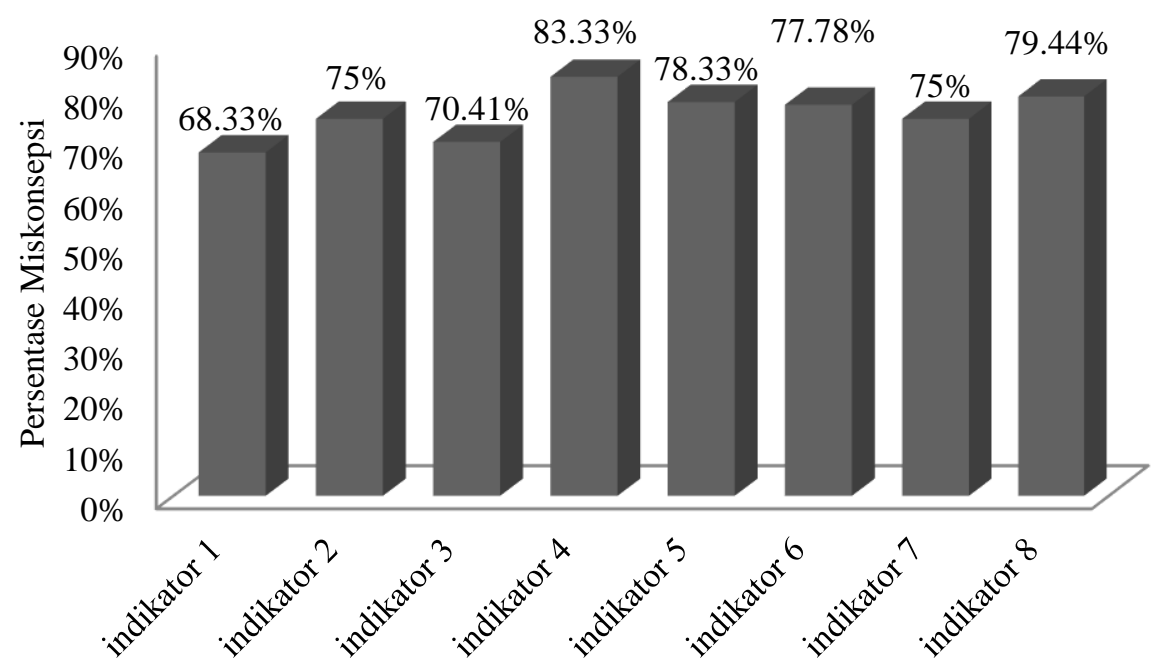

Gambar 3. Pemahaman Konsep Kategori Miskonsepsi

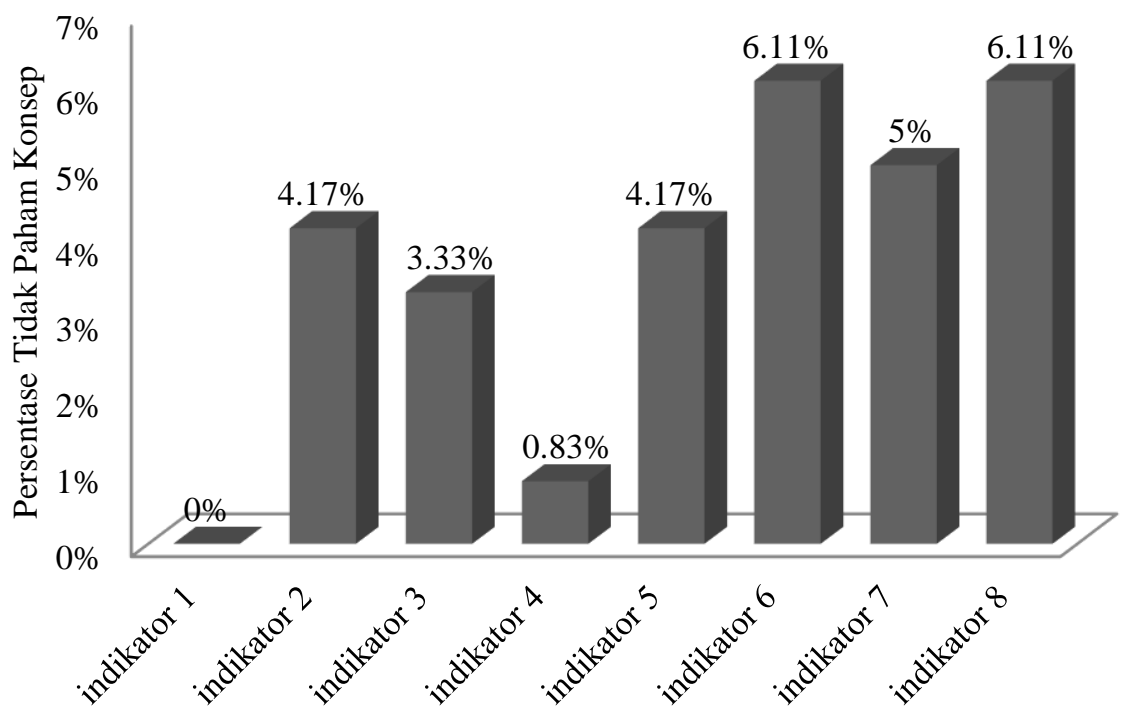

Gambar 4. Pemahaman Konsep Kategori Tidak Paham Konsep

Kategori pemahaman konsep siswa selanjutnya adalah tidak paham konsep. Siswa yang tidak paham konsep merupakan siswa yang tidak mampu menghubungkan antara apa yang mereka pelajari dengan bagaimana pengetahuan tersebut akan dipergunakann atau dimanfaatkan. Jawaban siswa yang tidak paham konsep tidak relevan dan tidak logis [14]. Saat menjawab three tier test, siswa yang tidak paham konsep menjawab salah pada tier pertama dan tier kedua, serta tidak yakin terhadap jawabannya. Siswa yang tidak menjawab atau tidak mengisi three tier test dapat juga digolongkan siswa yang tidak paham konsep.

Hasil yang diperoleh pada Gambar 4 menunjukkan bahwa siswa paling banyak tidak memahami konsep pada indikator 6 dan 8 sebesar $6.11 \%$ yang diklasifikasikan rendah dan siswa yang tidak memahami konsep paling sedikit pada indikator
1 sebesar $0.00 \%$ yang diklasifikasikan rendah. Dimana antara indikator 6 dan 8 yang paling banyak tidak memahami konsep yaitu indikator 6 konsep spermatogenesis pada soal nomor 9. Tidak memahami konsep terjadi karena materi pembelajaran yang tidak tersampaikan dengan baik sehingga siswa tidak memahami konsep. Siswa yang tidak memahami konsep saat pembelajaran daring/online dilakukan kemungkinan akan mencoba memahami sendiri konsep tersebut melalui buku atau referensi lainnya yang memungkinkan miskonsepsi terjadi. Hal ini didukung oleh Septiana [15] yang menyatakan bahwa siswa yang tidak memahami konsep tidak mampu menjelaskan kembali konsep yang telah dipelajarinya. Siswa yang tidak memahami konsep akan memberikan respon yang tidak jelas.

Kategori terakhir dari pemahaman konsep siswa adalah menebak. Menebak dalam Kamus Besar 
Bahasa Indonesia diartikan sebagai menerka, menduga, atau mengira. Siswa yang menebak dengan benar akan mendongkrak skor siswa sehingga menyebabkan estimasi (skor yang diperoleh seorang siswa) yang terlalu tinggi jika dibandingkan kemampuan siswa yang sesungguhnya [16]. Salah satu keunggulan three tier test adalah dapat membedakan siswa yang menebak dengan kategori pemahaman konsep lainnya.

Terdapat dua pola jawaban siswa yang menebak. Pertama, siswa benar pada tier pertama, tetapi salah pada tier kedua, dan tidak yakin terhadap jawabannya. Kedua, siswa salah pada tier pertama, benar pada tier kedua, dan tidak yakin terhadap jawabannya.

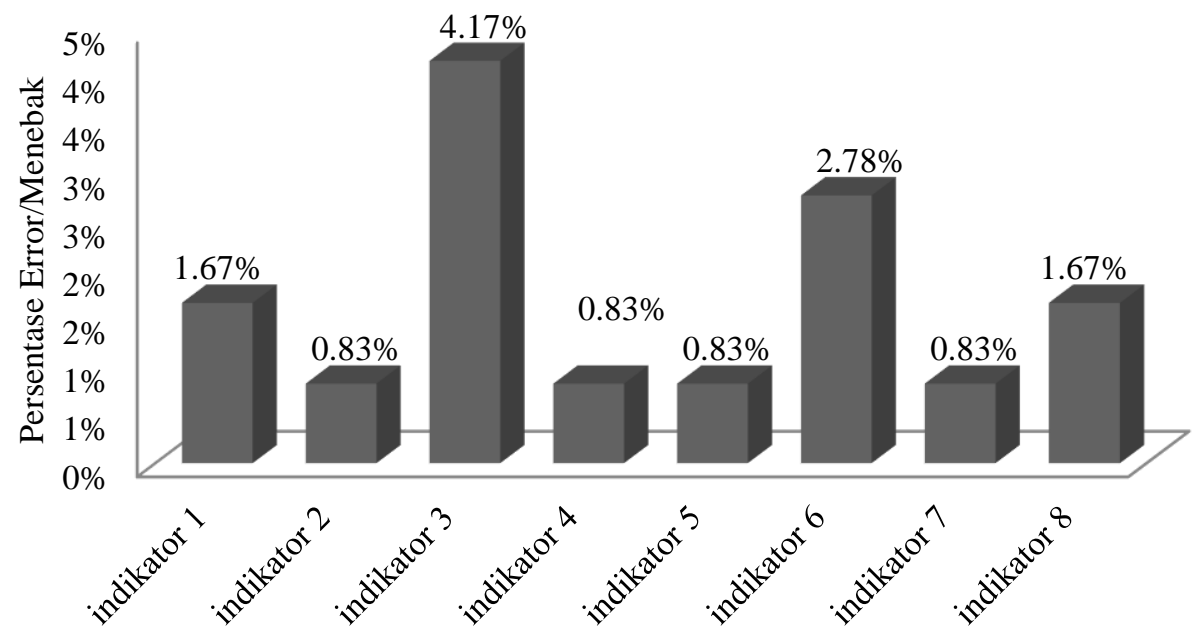

Gambar 5. Pemahaman Konsep Kategori Error/Menebak

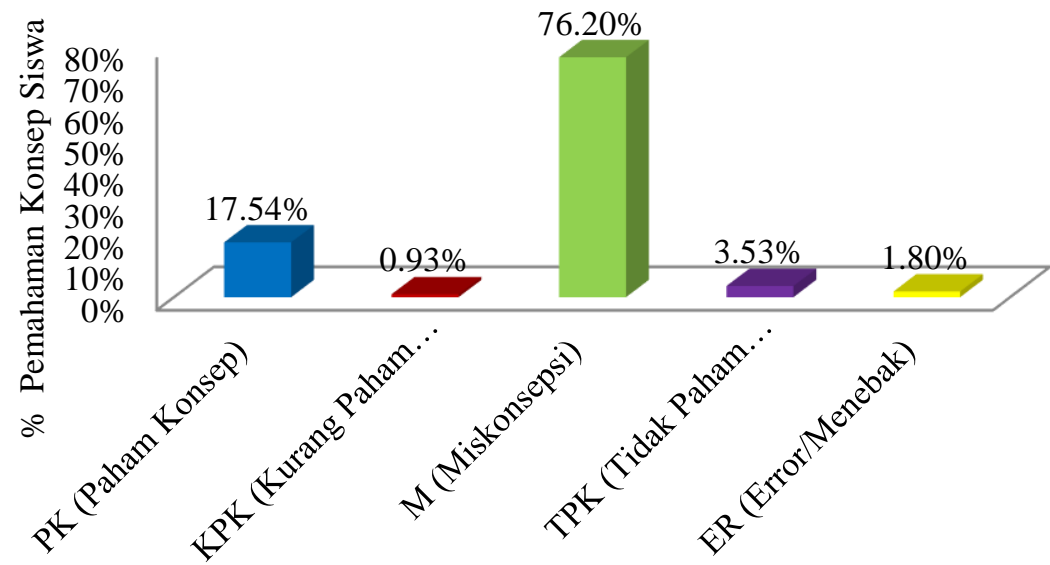

Gambar 6. Pemahaman Konsep Sistem Reproduksi Siswa Kelas XI MAN 1 Lombok Barat

Hasil yang diperoleh pada Gambar 5 menunjukkan bahwa siswa paling banyak menebak pada indikator 3 sebesar $4.17 \%$ yang diklasifikasikan rendah dan siswa yang menebak paling sedikit pada indikator 2, 4, 5 dan 7 sebesar $0.83 \%$ yang diklasifikasikan rendah. Pada indikator 3 tersebut siswa paling banyak menebak pada konsep spermatogenesis yaitu soal nomor 6. Dalam hal ini, jawaban siswa pada tingkatan pertama benar, tingkatan kedua salah dan siswa tidak yakin atas jawabannya sehingga pemahaman konsep siswa dikategorikan menebak. Siswa menebak karena adanya tingkat tidak yakin yang tinggi terhadap suatu pilihan jawaban. Tidak yakin tersebut dapat berasal dari kehidupan sehari-hari atau pengalaman pribadi siswa yang dibawa oleh siswa (prakonsepsi).

Prakonsepsi yang salah dan tidak berubah setelah dilaksanakannya kegiatan pembelajaran akan melekat pada struktur kognitif siswa sehingga menjadi miskonsepsi yang kemudian sulit untuk diubah. Oleh karena itu, menebak adalah bagian dari prakonsepsi yang didasari intuisi sehingga termasuk dalam kategori miskonsepsi. Hal tersebut didukung oleh Muniri [17] yang menyatakan bahwa menebak dapat dilakukan karena adanya intuisi siswa yang kuat. Sejalan dengan hal tersebut, Suparno [11] menyatakan pemikiran siswa yang intuitif ini sering 
membuat siswa tidak kritis dan mengakibatkan miskonsepsi.

Berdasarkan jawaban three tier test yang dilakukan di MAN 1 Lombok Barat, secara keseluruhan dari hasil penelitian pemahaman konsep sistem reproduksi teridentifikasi siswa paling banyak mengalami miskonsepsi sebesar $76.20 \%$ diklasifikasikan sangat tinggi baik pada konsep dengan ranah kognitif rendah maupun pada ranah kognitif tinggi dan paling sedikit siswa yang kurang paham konsep sebesar $0.93 \%$ diklasifikasikan rendah (Gambar 6). Hal ini menunjukkan bahwa konsepkonsep pada materi sistem reproduksi manusia masih sulit dipahami oleh siswa. Hal ini didukung oleh Prokop dan Fancovicova [18] yang menyatakan bahwa pemahaman responden masih banyak yang rendah atau mengalami miskonsepsi terutama pada konsep pencernaan, pernafasan, endokrin, urinary, reproduksi dan saraf.

Faktor utama tingginya persentase siswa yang mengalami miskonsepsi pada materi sistem reproduksi ini adalah metode pembelajaran yang dilakukan melalui daring/online semasa pandemi Covid-19 sehingga memperlihatkan ketidaksiapan siswa dalam menerima materi yang disampaikan dan siswa belum sepenuhnya memahami apa yang telah disampaikan oleh guru yang menyebabkan siswa kesulitan dalam mengingat dan memahami konsepkonsep yang abstrak karena materi sistem reproduksi prosesnya terjadi di dalam tubuh. Hal tersebut dapat menyebabkan pemahaman konsep siswa yang tidak utuh dan tidak kuat mengakibatkan kurangnya kemampuan penalaran siswa saat menghadapi pertanyaan Three Tier Test dengan alasan terbuka. Hal ini didukung oleh Murni [19] yang menyatakan bahwa metode mengajar yang digunakan guru dapat menyebabkan siswa mengalami miskonsepsi. Sejalan dengan hal tersebut Wibowo [20] menyatakan bahwa seseorang sulit memahami konsep-konsep yang bersifat pemahaman dalam belajar, sehingga cenderung memberikan efek yang kurang baik terhadap pemahaman konsep seseorang. Faktor yang menyebabkan siswa sulit untuk memahami konsep belajar adalah karena kurangnya motivasi belajar dan adanya kesulitan belajar sehingga dengan motivasi yang kurang menyebabkan seseorang malas untuk belajar sehingga menyebabkan rendahnya pemahaman konsep seseorang.

Miskonsepsi dalam penelitian ini juga disebabkan karena selama ini siswa dibiasakan dengan soal-soal sederhana tanpa dituntut untuk memberikan alasan atau penjelasan dari jawaban yang diperolehnya dan mayoritas siswa hanya mengenal kata-kata atau istilah tanpa memahami konsepnya sehingga konsep yang dimiliki siswa belum lengkap. Hal ini diperkuat dengan banyaknya siswa yang menjawab pilihan ganda benar tanpa memberikan alasan atau alasan yang diberikan keliru dengan kata lain tidak sesuai dengan konsep ilmiah. Pendapat ini didukung oleh Ibrahim [21] yang menyatakan bahwa miskonsepsi pada siswa sering terjadi karena penguasaan konsep oleh siswa belum lengkap, sederhana dan berbeda, siswa belum mampu membedakan atribut (ciri penentu) dari sejumlah ciri umum yang dimiliki oleh sebuah konsep, siswa tidak menguasai konsep prasyarat dari suatu konsep dan sumber belajar siswa yang memuat uraian materi yang salah dapat berkontribusi dalam meningkatkan miskonsepsi siswa.

Faktor lain penyebab terjadinya miskonsepsi pada siswa dalam penelitian ini, bersumber dari pemikiran siswa itu sendiri. Artinya, pemikiran tersebut dapat diperoleh dari interpretasi yang dibuat sendiri ketika membaca buku teks atau soft-file maupun power point yang diberikan guru dalam pelaksanaan pembelajaran melalui daring/online. Hal ini didukung oleh Ardiyanti [22] menyatakan kecenderungan siswa mengalami miskonsepsi karena kesalahan siswa dalam menginterpretasikan pemahamannya tentang materi sistem reproduksi berdasar pada penjelasan guru dan buku teks yang di baca. Sejalan dengan hal tersebut Chaniarosi [23] menyatakan bahwa miskonsepsi yang bersumber dari buku teks sangat berbahaya, karena selain guru salah dalam memahami konsep, maka peserta didik juga akan mengalami miskonsepsi yang sama. Sedangkan menurut Hairy [12] kesalahan dalam pemahaman konsep (miskonsepsi) merupakan salah satu masalah besar dalam pendidikan yang harus segera diselesaikan. Miskonsepsi banyak terjadi tidak hanya pada siswa saja tetapi dalam buku pun masih ditemukan miskonsepsi, akibatnya banyak pemahaman keliru yang harus segera dibenarkan.

Miskonsepsi yang terjadi dalam diri siswa lebih cenderung menetap dan sulit untuk diubah sehingga dapat mempengaruhi proses belajar mengajar berikutnya. Miskonsepsi siswa harus segera diatasi dan dicegah, karena miskonsepsi dapat menyebabkan siswa mengalami kegagalan dalam memahami konsep ilmiah sehingga dapat menurunkan prestasi belajar siswa [24]. Tindakan yang dapat dilakukan ketika siswa mengalami miskonsepsi adalah dengan melakukan langkahlangkah persuasif, seperti mencoba sesering mungkin membuat pertanyaan-pertanyaan yang sifatnya lisan, selalu menyimpulkan akhir bahasan setiap konsep dan harus dimulai pembiasaan-pembiasaan untuk mencari ragam konteks untuk menjelaskan sebuah konsep dan lain sebagainya. Hal ini memungkinkan dengan pembiasaan siswa dapat mulai bisa membuka diri untuk menyampaikan pemahaman yang ada dalam pikirannya sehingga dengan mudah bagi seorang guru mengetahui siswa tersebut mengalami miskonsepsi atau tidak [22].

\section{KESIMPULAN DAN SARAN}

Berdasarkan hasil penelitian pemahaman konsep sistem reproduksi melalui penggunaan instrumen three tier test yang dilakukan di Kelas XI MAN 1 Lombok Barat, siswa teridentifikasi 
mengalami miskonsepsi sangat tinggi pada konsepkonsep pemahaman yang rendah maupun yang membutuhkan pemahaman tinggi.

Saran yang dapat diberikan peneliti untuk dapat mencegah terjadinya miskonsepsi pada siswa yaitu guru harus memperbaiki kualitas metode pengajaran yang tepat sesuai karakteristik materi yang diajarkan ke siswa, sehingga siswa mudah memahami materi yang diajarkan dan bagi peneliti lain yang akan melakukan penelitian tentang pemahaman konsep siswa, diharapkan dapat melakukan penelitian lebih lanjut dengan mengembangkan instrumen tes diagnostik dengan metode mengajar yang tepat untuk keberhasilan siswa dalam pembelajaran.

\section{DATAR PUSTAKA}

[1] Permendiknas. (2006). Peraturan Menteri Pendidikan Republik Indonesia Nomor 22 Tahun 2006 tentang Standar Isi untuk Satuan Pendidikan Dasar dan Menengah. Jakarta.

[2] Nardi, S. A. \& Sugianto. (2015). Pembelajaran Model Cooperative Learning Tipe Jeis untuk Meningkatkan Sikap Ilmiah dan Pemahaman Konsep. Journal of Primary Education. 4 (1). 5662.

[3] Novitasari, Dian. 2016. Pengaruh Penggunaan Multimedia Interaktif Terhadap Kemampuan Pemahaman Konsep Matematis siswa. Jurnal pendidikan Matematika. 2 (2). 8-18.

[4] Sudijono, A. (2013). Pengantar Evaluasi Pendidikan. Jakarta: Raja Grafindo Persada.

[5] Suhendi H.Y., Ida K., \& Johar M. (2014). Peningkatan Pemahaman Konsep dan Profil Miskonsepsi Siswa Berdasarkan Hasil Diagnosis Menggunakan Pembelajaran ECIRR Berbantuan Simulasi Vitrual dengan Instrumen Three Tier Test. Prosiding Mathematics and Sciences Forum. 3 (1). 96-112.

[6] Suwarto. (2013). Pengembangan Tes diagnostic dalam Pembelajaran Panduan Praktis bagi Pendidik dan Calon Pendidik. Yogyakarta: Pustaka Pelajar.

[7] Bodner, G. M. (1986). Contructivism: a Theory of Knowledge. Journal of Chemical Education. 3 (63). 873-878.

[8] Surapranata, S. (2004). Panduan Penulisan Tes Tertulis Implementasi Kurikulum. Bandung: Remaja Rosdakarya.

[9] Daud, S. A. S., Laliyo L. A. R., \& Tangio J. S. (2014). Identifikasi Pemahaman Konsep Perubahan Wujud Zat dengan Menggunakan Instrumen Tiga Tingkat (Three-tier test) pada Siswa Kelas VII MTs Negeri Model Limboto. Jurnal Penelitian. 3 (2). 1-14.

[10] Kesumawati, N. (2008). Pemahaman Konsep Matematik dalam Pembelajaran Matematika.
Semnas Matematika dan Pendidikan Matematika. Universitas PGRI Palembang.

[11] Suparno, P. (2005). Miskonsepsi dan Perubahan Konsep dalam Pendidikan Fisika. Jakarta: PT Grasindo.

[12] Hairy, M. R., Kusmiyati \& M. Yamin. (2018). Analisis Penguasaan Konsep Materi Sistem Reproduksi pada Siswa SMA Negeri di Kota Mataram. Jurnal Pijar MIPA. 13 (2). 119-121.

[13] Campbell, N. A., \& Jane B. R.. (2003). Biologi Edisi kelima Jilid 3. Jakarta: Erlangga.

[14]Fitria. (2013). Efektivitas Penggunaan Multimedia Interaktif dalam Upaya Meminimalisasi Miskonsepsi Siswa pada Materi Pokok Larutan Penyangga. Skripsi. Universitas Negeri Semarang.

[15] Septiana, D., Zulfani \& Meiry F. N. (2014). Identifikasi Miskonsepsi Siswa pada Konsep Archaebacteria dan Eubacteria Menggunakan Two-Tier Multiple Choice. Edusains. 4 (2). 191200.

[16] Musmuliadi. (2009). Hubungan Model Penskoran terhadap Estimasi Skor Sesungguhnya Berdasarkan Teori Respon Butir. Jurnal Penelitian dan Evaluasi Pendidikan. 13 (2). 246267.

[17] Muniri. (2013). Karakteristik Berpikir Intuitif Siswa dalam Menyelesaikan Masalah Matematika. Yogyakarta: FMIPA UNY.

[18] Prokop, P., \& Jana F. (2006). Student's Idea About the Human Body: do They Really Draw What They Know?. Journal of Batic Science Education. 2 (10). 86-95.

[19] Murni, D. (2013). Identifikasi Miskonsepsi Mahasiswa pada Konsep Substansi Genetika Menggunakan Certainty of Response Index (CRI). Prosiding Semirata FMIPA Universitas Lampung.

[20] Wibowo, A. M. (2011). Dampak Pendidikan Agama Islam Terhadap Perilaku Reproduksi Sehat Siswa. Jurnal Analisa. 18 (2). 23-31.

[21] Ibrahim, M. (2012). Konsep, Miskonsepsi dan Cara Pembelajaran nya. Surabaya: Unesa University Press.

[22] Ardiyanti, Y., \& Marsah R. U. (2017). Identifikasi Miskonsepsi Siswa pada Materi Sistem Reproduksi. Biosfer, Jurnal Biologi dan Pendidikan Biologi. 2 (2). 18-23.

[23] Chaniarosi, L. F. (2014). Identifikasi Miskonsepsi Guru Biologi SMA Kelas XI IPA pada Konsep Sistem Reproduksi Manusia. Jurnal Education Biology Tropika. 2 (2). 187-250.

[24] Setiawati, G.A.D., Arjaya, I.B.A., \& Ni Wayan, E. (2014). Identifikasi Miskonsepsi Materi Fotosintesis \& Respirasi Tumbuhan Siswa Kelas IX SMP Kota Denpasar. Jurnal Bakti Saraswati. 3 (2). 14-28. 